\title{
Calibration of a bioenergetics model linking primary production to Atlantic menhaden Brevoortia tyrannus growth in Chesapeake Bay
}

\author{
Eric R. Annis ${ }^{1,3, *}$, Edward D. Houde ${ }^{1}$, Lawrence W. Harding Jr. ${ }^{2}$, \\ Michael E. Mallonee ${ }^{2,4}$, Michael J. Wilberg ${ }^{1}$ \\ ${ }^{1}$ Chesapeake Biological Laboratory, University of Maryland Center for Environmental Sciences, PO Box 38, Solomons, \\ Maryland 20688, USA \\ ${ }^{2}$ Horn Point Laboratory, University of Maryland Center for Environmental Sciences, PO Box 775, Cambridge, \\ Maryland 21613, USA \\ ${ }^{3}$ Present address: Hood College, Biology Department, 401 Rosemont Avenue, Frederick, Maryland 21701, USA \\ ${ }^{4}$ Present address: Interstate Commission on the Potomac River Basin, 51 Monroe Street, Suite PE-08, Rockville, \\ Maryland 20850, USA
}

\begin{abstract}
Growth and potential productivity of young-of-the-year (YOY) Atlantic menhaden Brevoortia tyrannus, a key forage fish, were investigated in Chesapeake Bay. A coupled foraging and bioenergetics model was developed to predict the dependency of menhaden size on chlorophyll $a(\mathrm{chl} a)$ and water temperatures in the bay. Substantial improvements were made to functional responses previously developed to describe YOY menhaden filtering efficiency on phytoplankton and swimming speed while filter feeding. Model output was calibrated to correspond to observed lengths of field-collected menhaden over an $11 \mathrm{yr}$ period (1995 to 2005) by adjusting the percentage of chl a available to menhaden in the model. The model effectively represents variability in menhaden length in response to changes in chl $a$ and temperature, indicating that only $9.2 \%$ of available chl a was required for menhaden to grow to lengths observed in the bay. In simulations of growth potential by bay region, the oligohaline (upper) region had the highest growth potential with decreasing potential in the mesohaline (middle) and polyhaline (lower) regions of the bay. Our results represent the first rigorous calibration and evaluation of a coupled foraging-bioenergetics model for Atlantic menhaden and establish a quantitative link between chl a standing stock and menhaden growth potential.
\end{abstract}

KEY WORDS: Bioenergetics - Atlantic menhaden - Brevoortia tyrannus - Chesapeake Bay · Trophic linkage $\cdot$ Primary consumers

Resale or republication not permitted without written consent of the publisher

\section{INTRODUCTION}

The Atlantic menhaden Brevoortia tyrannus is a key forage fish in coastal waters and estuaries on the east coast of North America. Historically, it also has supported the largest single-species fishery in that region. Declines in recruitment in the past 2 decades, combined with mandates to develop ecosystem- based management plans, have fostered increasing interest in the role of menhaden as prey for its many predators, the effect of estuarine water quality on young-of-the-year (YOY) recruitment (CBFEAP 2006, MDSG 2009, ASMFC 2010), and the role of menhaden filter-feeding on water quality (Dalyander \& Cerco 2010, Lynch et al. 2010). Our research is aimed at understanding the linkage between envi- 


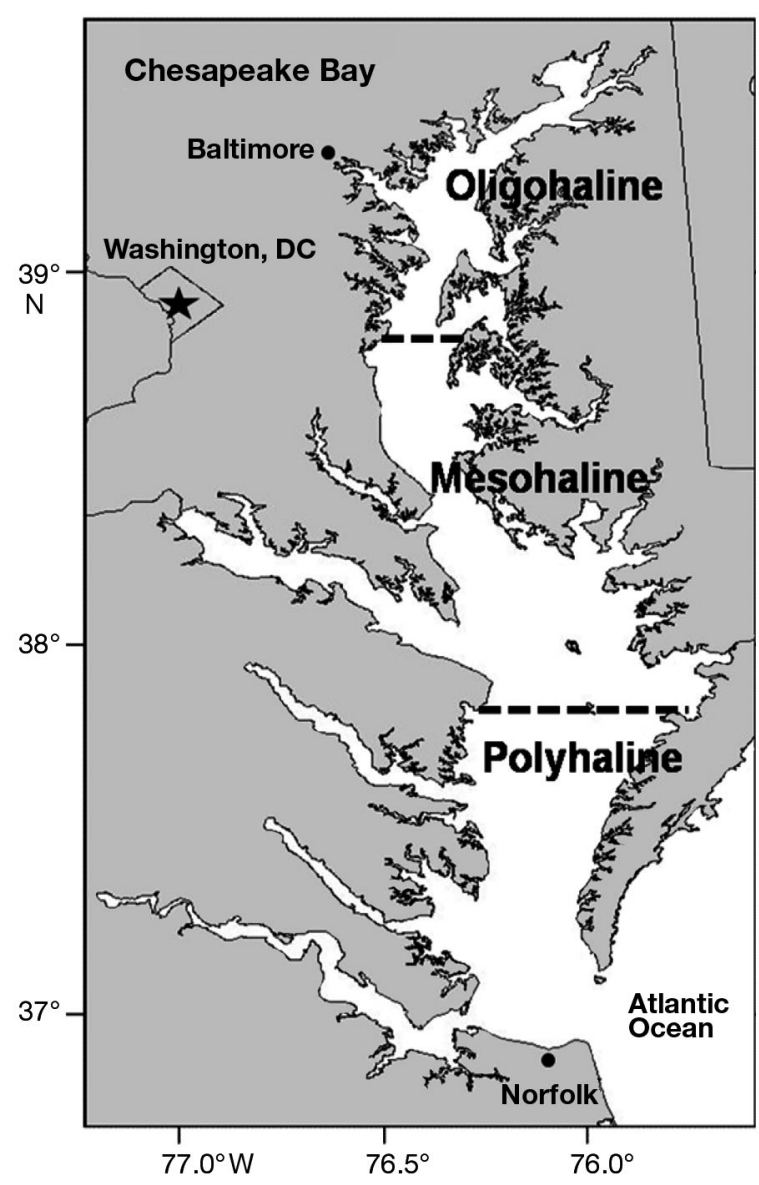

Fig. 1. Chesapeake Bay, showing the 3 regions defined by salinity: oligohaline (salinity < 10, 38.81 to $39.66^{\circ} \mathrm{N}$ ), mesohaline $\left(10<\right.$ salinity < 20, 37.81 to $\left.38.80^{\circ} \mathrm{N}\right)$, and polyhaline (salinity $>20,36.95$ to $37.80^{\circ} \mathrm{N}$ )

ronmental factors, especially primary production in Chesapeake Bay (Fig. 1) and the growth, production, and recruitment of Atlantic menhaden. Here, we present a calibrated bioenergetics model that explains a substantial portion of inter-annual variability in growth of YOY menhaden in Chesapeake Bay.

Atlantic menhaden plays an important role in transferring energy up the food web and supports large-scale reduction and bait fisheries. As a primary consumer, YOY menhaden filter-feeds on phytoplankton, directly transferring primary production to menhaden production. Menhaden is often categorized as the most important forage species on the North American Atlantic coast for piscivorous fishes, birds, invertebrates, and marine mammals (Ahrenholz 1991, Hartman \& Brandt 1995, Walter et al. 2003, Viverette et al. 2007, MDSG 2009). Chesapeake Bay serves as a major nursery for YOY menhaden and may contribute as much as $69 \%$ of recruits to the coast-wide adult population (Ahrenholz et al. 1989). Economically, Atlantic menhaden constitutes the single largest fishery in Chesapeake Bay, with landings often exceeding 100000 metric tons (Smith 1999). Despite the importance of menhaden in Chesapeake Bay, the roles of phytoplankton supply and possible bottom-up control of menhaden productivity are poorly defined.

Bioenergetics modeling offers a means to explore linkages between primary production and menhaden growth, and to quantify trophic interactions that are a cornerstone for evolving ecosystem-based management (MDSG 2009). In aquatic ecosystems, application of the 'Wisconsin Model' (Ney 1990, Hanson et al. 1997) in fisheries biology and management has become increasingly common over the past 3 decades (Hartman \& Kitchell 2008). While insightful, many applications of bioenergetics models, including those for Atlantic menhaden, remain uncorroborated due to inherent difficulties in obtaining sufficient field data on fish diets and consumption (reviewed in Chipps \& Wahl 2008). Moreover, most bioenergetics modeling has not identified or corrected sources of error (Hartman \& Kitchell 2008). We compared menhaden size and growth data from Chesapeake Bay surveys with model results of a parameterized, coupled foraging-bioenergetics model for YOY Atlantic menhaden. The model presented here was developed to quantify the linkage between primary production and menhaden growth.

Our modeling focused on YOY menhaden that have undergone an ontogenetic transition in diet and habitat during their first summer in coastal estuaries. Levels of consumption and growth during this period may determine the size and numbers of menhaden recruiting to the coastal population in late fall when they egress from Chesapeake Bay. The menhaden life cycle begins on the continental shelf in the fall to winter months, where eggs and larvae develop before entering coastal bays primarily during winter months (Reintjes \& Pacheco 1966, Rogers \& Van den Avyle 1983). Larvae, including late-stage larvae ( 28 to $35 \mathrm{~mm}$ ), feed selectively on zooplankton, particularly copepods (June \& Carlson 1971). Filter-feeding capability on phytoplankton develops post metamorphosis in small juveniles at lengths of 30 to $50 \mathrm{~mm}$, after entry into estuaries (June \& Carlson 1971). Detritus and zooplankton may comprise a significant fraction of the juvenile diet, particularly in proximity to salt marshes where detritus from vascular plants occurs in stomachs (Lewis \& Peters 1981, 1984, 1994). The retention of small particles by YOY menhaden suggests that nanoplankton and bacteria may be 
included in the diet (Friedland et al. 1984). Friedland et al. (2006) hypothesized, and Lynch et al. (2010) demonstrated, that another transition occurs between 100 and $200 \mathrm{~mm}$ length as gillraker spacing widens and becomes less efficient at retaining small phytoplankton. For example, a $138 \mathrm{~mm}$ menhaden can retain particles in the 5 to $7 \mu \mathrm{m}$ range (Friedland et al. 1984), but a $257 \mathrm{~mm}$ menhaden could only retain particles $>13 \mu \mathrm{m}$ (Durbin \& Durbin 1975).

Spatially explicit bioenergetics models for YOY menhaden in Chesapeake Bay and its tributaries were developed previously to estimate carrying capacity and the effects of nutrient loading and low dissolved oxygen on available habitat and menhaden production potential (Luo et al. 2001, Brandt \& Mason 2003). Additionally, Gottlieb (1998) and Dalyander \& Cerco (2010) used bioenergetics modeling to estimate the potential impact of menhaden filter feeding on primary production, nutrient sequestration, and phytoplankton standing stock in Chesapeake Bay. Parameters for those models were estimated by Rippetoe (1993), based on laboratory experiments, literature review, and field collections of YOY menhaden that were limited to 1 location and 1 season. Luo et al. (2001) developed a foraging submodel to estimate prey (phytoplankton) consumption as a function of swimming speed, filtering efficiency, mouth size, and chlorophyll a (chl a) concentration. The models developed in these studies demonstrated the potential of bioenergetics models as a tool to estimate the impact of water quality on menhaden growth potential and, conversely, the effect of menhaden on water quality. However, none of these models were calibrated by comparing observed menhaden size in the bay with modeled menhaden size generated using chl $a$ and temperature measurements corresponding to the temporal and spatial domain in which the menhaden were collected.

We adopted the fundamental modeling approach of Luo et al. (2001). Our goal was to develop a calibrated bioenergetics model that accurately predicted growth and sizes of menhaden observed in fisheries surveys of Chesapeake Bay. We accomplished this by improving the functional responses for foraging efficiency and swimming speed and by calibrating and statistically fitting the model to field observations. The functional responses in earlier foraging models (Luo et al. 2001, Brandt \& Mason 2003, Dalyander \& Cerco 2010) were revised to incorporate new knowledge of the ontogenetic changes in gillraker spacing that affect filtering efficiency (Friedland et al. 2006) and a better understanding of swimming speeds during foraging.

\section{MATERIALS AND METHODS}

Model framework. We adopted the bioenergetics model framework of Kitchell et al. (1977), most recently updated by Hanson et al. (1997). The bioenergetics model was coupled with a menhaden foraging model first developed by Luo et al. (2001) that we improved by revising the functional responses for swimming speed and filtering efficiency. The coupled model was run to estimate growth potential and YOY menhaden lengths as a function of varying temperatures and chl a levels (food availability) in Chesapeake Bay over an 11 yr period (1995 to 2005).

\section{Chlorophyll and temperature}

Data on surface chl a were obtained from the Chesapeake Bay Remote Sensing Program (CBRSP), which collects ocean color measurements from lowaltitude aircraft flights (Harding et al. 1994, 2005). Approximately biweekly flights collected data at a spatial resolution of tens-of-meters along regular flight tracks that encompass the mainstem of Chesapeake Bay. A catalog of remotely sensed chl a observations is available online (www.cbrsp.org). Overflights were coordinated with shipboard surveys to calibrate and validate aircraft retrievals of chl a and bay surface temperature (Harding et al. 1994). Monthly averaged, surface chl a values for the entire bay and for 3 bay regions from 1995 to 2005 were calculated from the overflight data. Linear interpolation between months generated daily chl a values for the foraging model.

Temperature data were obtained from the Chesapeake Bay Program's biweekly monitoring surveys (www.chesapeakebay.net). Monthly averages of mean temperature for the entire bay and 3 bay regions were calculated for surface to $8 \mathrm{~m}$ depth in the mainstem of Chesapeake Bay. A sine function was fit to the monthly means for each year to allow interpolation of daily temperatures for input into both the foraging and bioenergetics models. The modeled seasonal temperature trends for each year, from which daily temperatures were estimated, were described by a sine function:

$$
T=y_{0}+a \times \sin (2 \times \pi \times D / b+c)
$$

where $T$ is temperature, $D$ is day of year, $y_{0}$ is the intercept, and $a, b$ and $c$ are coefficients (Table 1). The sine function regressions were significant $(p<$ 0.05 ) for all years, with $r^{2}>0.97$. Our model did not explicitly account for reduced growth potential due 
Table 1. Values for regression equations describing annual temperature data, depicted in Fig. 2 (1995 to 2005). Monthly average temperatures were fit to a sine function: $T=y_{0}+a \times$ $\sin (2 \times \pi \times D / b+c)$, where $T$ is temperature, $D$ is the day of year, $y_{0}$ is the intercept, and $a, b$, and $c$ are coefficients

\begin{tabular}{|ccccc|}
\hline Year & $y_{0}$ & $a$ & $b$ & $c$ \\
\hline 1995 & 15.54 & 12.31 & 347.80 & 4.02 \\
1996 & 14.00 & 12.49 & 361.05 & 4.10 \\
1997 & 14.51 & 11.06 & 356.52 & 4.06 \\
1998 & 16.22 & 10.56 & 356.17 & 4.00 \\
1999 & 15.33 & 11.21 & 380.38 & 4.27 \\
2000 & 13.94 & 11.74 & 393.00 & 4.49 \\
2001 & 14.34 & 11.78 & 398.91 & 4.40 \\
2002 & 15.69 & 11.51 & 355.48 & 4.16 \\
2003 & 14.09 & 12.16 & 361.30 & 4.07 \\
2004 & 14.21 & 12.00 & 404.29 & 4.51 \\
2005 & 15.96 & 12.59 & 336.18 & 3.79 \\
\hline
\end{tabular}

to below-pycnocline hypoxic waters in the summer, but our calculations were limited to the upper $8 \mathrm{~m}$ of the water column, which is typically within the mixed layer and where menhaden are likely to forage.

\section{Menhaden foraging model}

The foraging model of Luo et al. (2001) estimated daily weight-specific consumption (Cons $\mathrm{wt}^{-1}$ ) as a product of the area of a menhaden's mouth opening, its swimming speed, the concentration of food available, and the filtering efficiency of the gillrakers. Equations and parameters for our adjusted and modified foraging and bioenergetics models are provided in Tables $2 \& 3$. We modified the Luo et al. (2001) foraging model to include a term for the proportion of chl a available (pchl a) that expresses the fraction of chl $a$ input to the foraging model as a multiplier between 0 and 1.0. This term was estimated by minimizing the sum of squared differences between the bioenergetics model output and observed menhaden lengths in the bay. Mouth opening increased exponentially with menhaden length, and we adopted the function of Luo et al. (2001).

Swimming speed in our model was described as a function of temperature and menhaden length (Fig. 2A). To describe swimming as a function of temperature, we adopted a Gaussian-form curve (Table 3) similar to the bell-shaped functional responses reported for sockeye salmon Oncorhynchus nerka, coho salmon O. kisutch (Lee et al. 2003), and southern catfish Silurus meridionalis (Zeng et al. 2009). Our functional response had an asymptote at low temperatures, a strong positive response to increasing temperature, and a decrease in swimming speed at the highest temperatures. The maximum swimming speed (1.99 body lengths [BL] $\left.\mathrm{s}^{-1}\right)$ and optimum temperature $\left(26^{\circ} \mathrm{C}\right)$ in this function were based on the maximum swimming speed of feeding YOY menhaden at 24.4 to $27.2^{\circ} \mathrm{C}$ (Friedland et al. 1984). Our function incorporated a lower maximum swimming speed and higher minimum swimming speed than the sigmoidal function used by Luo et al. (2001) that did not include a reduction in swimming speed at high temperatures.

We developed a new function to relate filtering efficiency to menhaden length based on new information on ontogenetic changes in gillraker morphology. Friedland et al. (2006) found that the spacing between branchiospinules increased nonlinearly with menhaden length and proposed that filtering efficiency would be inversely proportional to branchiospinule spacing. Accordingly, we inverted the Friedland et al. relationship (Fig. 8 in Friedland et al. 2006) to provide a generalized func-

Table 2. Brevoortia tyrannus. Atlantic menhaden bioenergetics model parameters derived by Rippetoe (1993) and used previously by Luo et al. (2001), Brandt \& Mason (2003), and Dalyander \& Cerco (2010). Terminology corresponds to the fish bioenergetics model of Hanson et al. (1997). SR: standard respiration. $C_{\max }=$ maximum consumption

\begin{tabular}{|lcl|}
\hline Parameter & Value & Description \\
\hline$C_{a}$ & 1.294 & Intercept for $C_{\max }$ \\
$C_{b}$ & -0.312 & Exponent for $C_{\max }$ \\
$K_{1}$ & 0.525 & Proportion of $C_{\max }$ at $T_{1}$ \\
$K_{2}$ & 0.980 & Proportion of $C_{\max }$ at $T_{2}$ \\
$K_{3}$ & 0.980 & Proportion of $C_{\max }$ at $T_{3}$ \\
$K_{4}$ & 0.810 & Proportion of $C_{\max }$ at $T_{4}$ \\
$T_{1}$ & 18.2 & Temperature for $K_{1}$ \\
$T_{2}$ & 28.0 & Temperature for $K_{2}$ \\
$T_{3}$ & 29.0 & Temperature for $K_{3}$ \\
$T_{4}$ & 30.1 & Temperature for $K_{4}$ \\
$R_{a}$ & 0.003301 & Intercept for maximum SR \\
$R_{b}$ & -0.2246 & Exponent for maximum SR \\
RQ & 2.07 & Slope for temperature dependence of SR \\
RTO & 33.0 & Optimum temperature for SR \\
RTM & 36.0 & Maximum temperature for SR \\
SDA & 0.172 & Specific dynamic action coefficient \\
ACT & $1+2.5 /\left[1+\mathrm{e}^{(-0.798 T+6.378)}\right]$ & Temperature-dependent activity coefficient \\
$F_{a}$ & 0.14 & Proportion of consumed food egested \\
$U_{a}$ & 0.10 & Proportion of assimilated food excreted \\
\hline
\end{tabular}


Table 3. Brevoortia tyrannus. Functions and relationships in the coupled foraging and bioenergetics model for young-of-theyear Atlantic menhaden. FL: fork length; TL: total length. See Table 2 for parameters

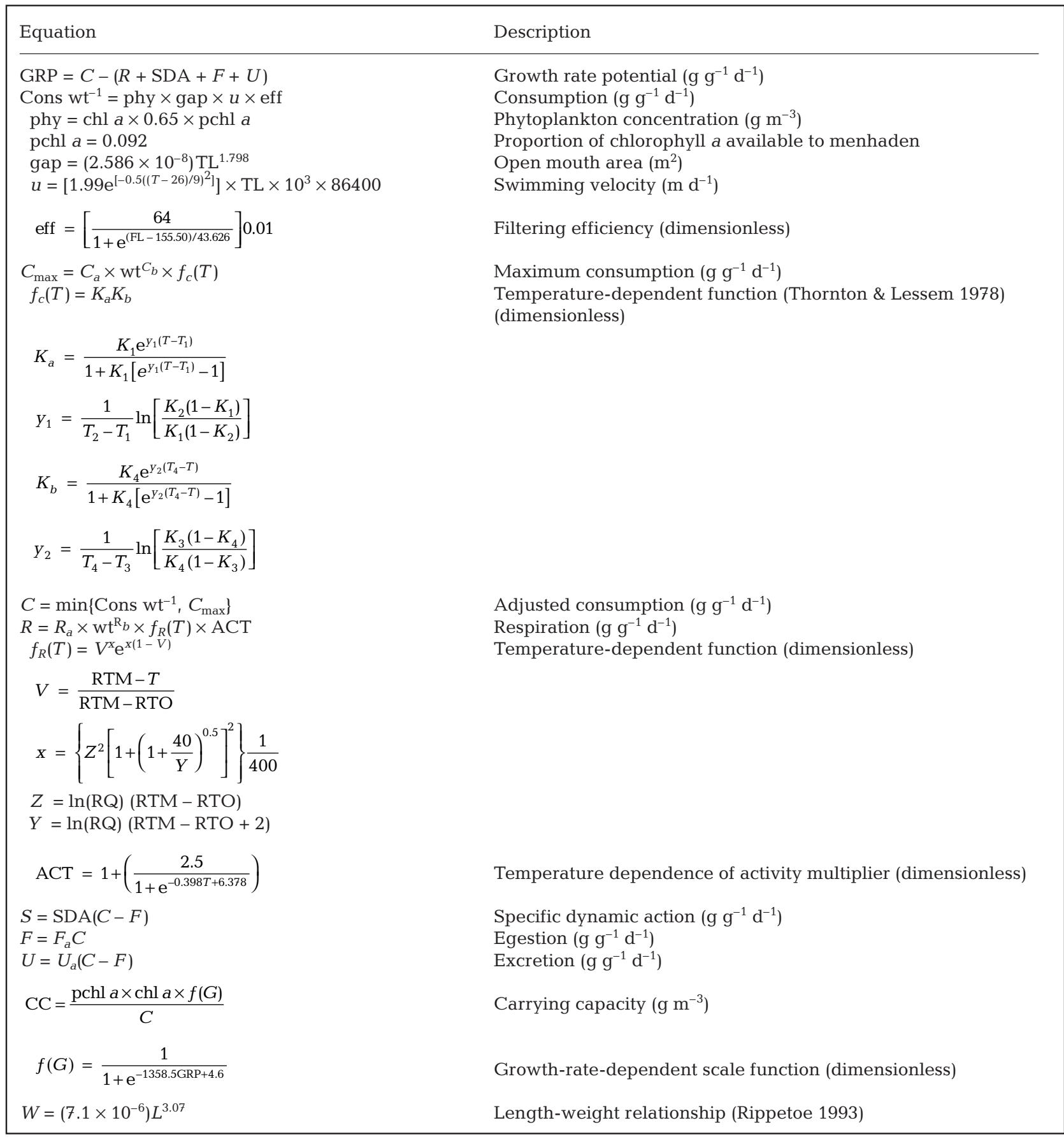

tion for filtering efficiency (Table 3). We converted fork length (FL, used by Friedland et al. 2006) to total length (TL) from the relationship: TL $=1.146 \times$ FL (www.fishbase.org). We then adjusted coefficients in our function to force the curve through the midpoints of 2 reported ranges for filtering efficiency (Fig. 2B). Observed filtering efficiency can vary greatly with respect to the size of particles being filtered (Durbin \& Durbin 1975, Friedland et al. 1984, Lynch et al. 2010). We used the filtering efficiency reported for diatom chains of Skeletonema costatum ranging from 1 to 6 cells ( 7 to $57 \mu \mathrm{m}$ in length; Friedland et al. 1984). Diatoms dominate the floral composition of Chesapeake Bay waters in 

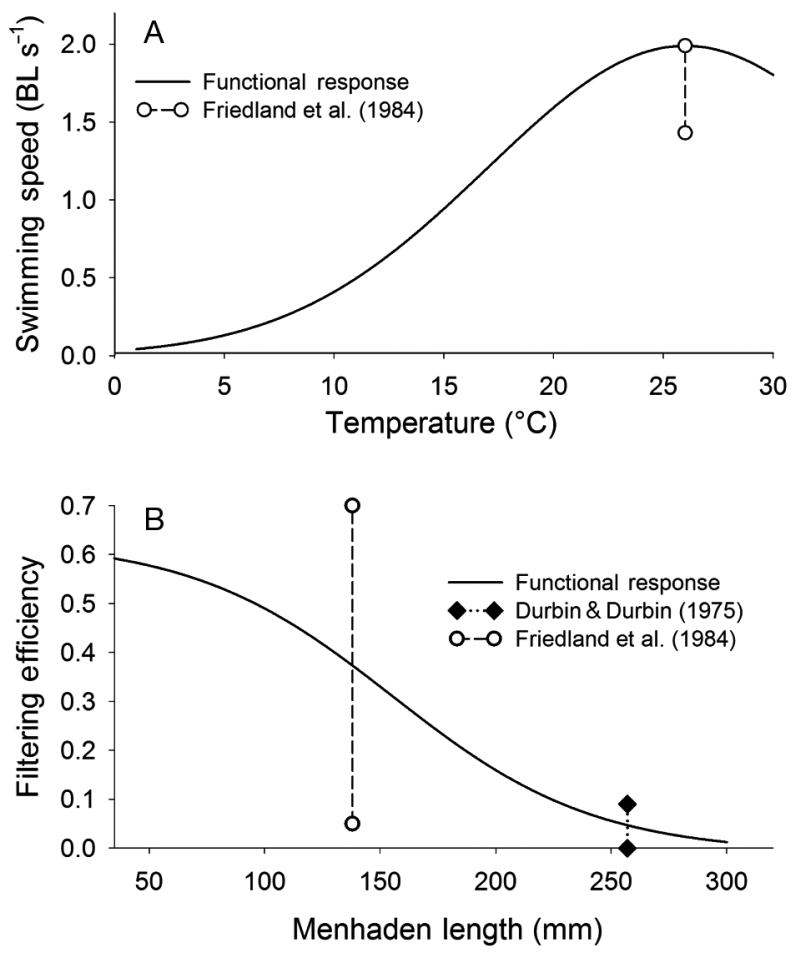

Fig. 2. Brevoortia tyrannus. (A) Atlantic menhaden swimming speed as a function of water temperature, and youngof-the-year menhaden swimming speeds while filterfeeding as reported by Friedland et al. (1984); BL = body length. (B) Filtering efficiency as a function of menhaden length (total length) based on the inverse of Friedland et al.'s (2006) reported relationship between menhaden length and gillraker spacing. Vertical bars indicate the range of reported filtering efficiencies on 1- to 6-cell chains of the diatom Skeletonema costatum for menhaden at 138 and $257 \mathrm{~mm}$ lengths (Durbin \& Durbin 1975, Friedland et al. 1984). Equations for these functional responses are provided in Table 3

the spring and fall and remain a substantial component even in the summer months (Adolf et al. 2006, Paerl et al. 2006). In particular, S. costatum is a dominant species in both spring and summer phytoplankton communities in the bay (Marshall et al. 2006). Single $S$. costatum cells ( $7 \mu \mathrm{m})$ represent the smallest size cell retained by filter-feeding menhaden, and efficiency increases with increasing chain length (Durbin \& Durbin 1975, Friedland et al. 1984). For 1- to 6-cell chains of $S$. costatum, a $138 \mathrm{~mm}$ menhaden filtered with an efficiency of 5 to $69 \%$ (Friedland et al. 1984), while a $257 \mathrm{~mm}$ menhaden filtered only with an efficiency of 0 to $9 \%$ (Durbin \& Durbin 1975). Similarly, Lynch et al. (2010) reported high filtration efficiency on $>7 \mu \mathrm{m}$ phytoplankton by $73.6 \mathrm{~mm}$ menhaden, but low filtration of phytoplankton by $188.7 \mathrm{~mm}$ menhaden.

\section{Modeled growth potential}

The model framework of Fish Bioenergetics 3.0 (Hanson et al. 1997) utilizes an energy budget approach in which potential growth equals consumption less respiration and waste. We reconstructed the model in Excel spreadsheets (Microsoft Office 2003) to facilitate forward running of the bioenergetics model coupled with the foraging model. The bioenergetics model incorporated menhaden-specific physiological parameters from Rippetoe (1993) and Luo et al. (2001) (Table 3). The model software calculates energy flow in joules, thus requiring a conversion from chl a concentration to joules. The wet-weight energy density for phytoplankton of $6.02 \mathrm{~kJ} \mathrm{~g}^{-1}$ (Rippetoe 1993) was converted from a dry-weight energy density of $18.82 \mathrm{~kJ} \mathrm{~g}^{-1}$ (Cummins \& Wuycheck 1971), using a dry weight to wet weight ratio of 0.32 (Peters \& Downing 1984). Chl a values were converted to phytoplankton biomass (wet wt) as in Luo et al. (2001), where $1.0 \mathrm{mg} \mathrm{m}^{-3} \mathrm{chl} a=0.65 \mathrm{~g} \mathrm{~m}^{-3}$ phytoplankton biomass. To convert menhaden wet weight (g) to length (mm), we used Rippetoe's (1993) lengthweight relationship (Table 3). To convert oxygen units to energy units in the respiration equations, we used the oxycalorific conversion of $13.6 \mathrm{~J} \mathrm{mg}^{-1} \mathrm{O}_{2}$ (Elliott \& Davison 1975).

As output, the model calculated daily potential growth rate $\left(\mathrm{g} \mathrm{g}^{-1} \mathrm{~d}^{-1}\right.$, wet $\left.\mathrm{wt}\right)$ on each day for an individual menhaden. Because our input chl $a$ and temperatures were mean values, the model output represented mean growth potential per individual. We calculated cumulative growth over all days in model runs from 1 April (day-of-year 91) to 1 November (day-of-year 305) to generate cumulative potential growth curves for each year (1995 to 2005). The mean initial length of menhaden entering the model in April, $37 \mathrm{~mm}$ TL, was estimated by fitting a logistic curve to monthly mean YOY menhaden lengths from historical trawl-survey data of the Virginia Institute for Marine Sciences from 1957 to 2003 (Houde et al. 2009).

Carrying capacity $\left(\mathrm{g} \mathrm{m}^{-3}\right.$, wet wt) of YOY menhaden (Table 3) was calculated based on our estimates of growth rate potentials and available phytoplankton, following the procedure of Brandt \& Mason (2003). Carrying capacity represents the maximum level of YOY menhaden biomass $\left(\mathrm{g} \mathrm{m}^{-3}\right)$ that can be sustained based on available phytoplankton biomass on any given day of the model run. As such it represents an estimate of potential carrying capacity rather than a production estimate. Total carrying capacity (number of menhaden) was scaled to the 
water volume of the top $8 \mathrm{~m}$ in the mainstem of Chesapeake Bay by multiplying carrying capacity values $\left(\mathrm{g} \mathrm{m}^{-3}\right)$ by the total water volume $(50 \times$ $109 \mathrm{~m}^{-3}$ ) in the bay's mainstem (Cronin 1971) and the proportion of the bay volume above $8 \mathrm{~m}$ depth, 0.75 (Boicourt et al. 1999). Carrying capacity was converted to number of menhaden by dividing biomassbased values (in $\mathrm{g} \mathrm{m}^{-3}$ ) by the mass of an individual on each day.

\section{Calibrating the model to observed growth}

We calibrated the model by estimating the proportion of chl a available for menhaden consumption so that model output fit observed trawl-survey menhaden lengths. Predicted length during the April through October period was estimated by running the model forward using a range of chl $a$ and temperature values specific to each year (1995 to 2005), and these predictions were compared to observed menhaden lengths in the bay for the corresponding year. The model was calibrated by adjusting the available chl $a$ (pchl a) to minimize the sum of squared differences between observed YOY menhaden lengths and modeled lengths. Our pchl a term (Table 3 ) is not the $\mathrm{p}$-value often utilized in bioenergetics models (Hanson et al. 1997). Our approach describes consumption as a proportion of the available food ( $\mathrm{chl} \mathrm{a}$ ) rather than a proportion of maximum consumption $\left(C_{\max }\right)$.

Observed menhaden lengths were obtained from midwater-trawl-sampled YOY menhaden in the TIES 1 and CHESFIMS 2 research surveys. Surveys were conducted in summer and fall for the years from 1995 to 2005 and included sampling sites along the entire length of Chesapeake Bay. The date of the midpoint of each survey used in our analyses occurred for summer surveys between 28 June (DOY

\footnotetext{
${ }^{1}$ TIES 'Trophic Interactions in Estuarine Systems' US National Science Foundation-funded Land Margin Ecosystem Research (LMER) project, funded from 1995 to 2000, University of Maryland Center for Environmental Science. Multiple Principal Investigator (PI) Interdisciplinary research on a Chesapeake Bay-wide scale, including physical oceanography, primary production, zooplankton, and fish components. E.D.H. was a co-PI.

${ }^{2}$ CHESFIMS 'Chesapeake Bay Fishery-Independent Multispecies Survey' NOAA Chesapeake Bay Office Fisheries Research Program, grant to University of Maryland Center for Environmental Science. This bay-wide midwater trawl and bottom-trawl survey was funded from 2001 to 2005. T. Miller was PI and E.D.H. co-PI (http://hjort.cbl.umces. edu/chesfims.html).
}

179) and 8 August (DOY 220), and for fall surveys between 10 September (DOY 253) and 1 November (DOY 305). The length ranges of YOY menhaden cohorts were verified from length-frequency distributions; there was virtually no overlap of YOY lengths with lengths of Age 1 or older cohorts. YOY lengths were $<180 \mathrm{~mm}$ for summer surveys and ranged from 50 to $220 \mathrm{~mm}$ for fall cruises. Length data were available from at least 2 surveys in each year, and data from additional surveys were available for 1997, 1998, and 1999. Mean YOY length from each survey was compared to the bioenergetics-model length for the corresponding year and the midpoint date of the survey. A root mean squared error (RMSE) was calculated based on the deviations of modeled lengths from observed lengths. The pchl a term was estimated by minimizing the RMSE using the Solver tool in Microsoft Excel, which is equivalent to minimizing the sum of squares. Length data from trawl surveys in 3 randomly selected years $(1998,2002$, and 2004) were withheld from the calibrating procedure and used to evaluate model performance.

Regional estimates of growth potential. To determine if growth potential differed among bay regions, growth was modeled in 3 regions for each year in our time series using regional temperature and $\mathrm{chl} a$ data. The 3 regions (Fig. 1) were defined by latitude (Harding et al. 2002) and designated as follows: polyhaline $\left(36.95\right.$ to $\left.37.80^{\circ} \mathrm{N}\right)$, mesohaline $(37.81$ to $\left.38.80^{\circ} \mathrm{N}\right)$, and oligohaline (38.81 to $\left.39.66^{\circ} \mathrm{N}\right)$. Mean projected menhaden lengths on 1 November were compared among the 3 regions.

\section{RESULTS}

Temperature and $\mathrm{chl}$ a values varied seasonally and interannually (Fig. 3). Chl a exhibited strong interannual variability with approximately 2-fold differences among years. In contrast, temperature had low interannual variability, but strong seasonality with a peak in late July or early August. Mean seasonal lengths of YOY menhaden from TIES and CHESFIMS cruises (1995 to 2005) ranged from $78.9 \mathrm{~mm}$ in 1999 to $157.2 \mathrm{~mm}$ in 1998 during summer and from $131.4 \mathrm{~mm}$ in 1999 to $183.9 \mathrm{~mm}$ in 1998 during fall. The mean lengths from the trawl surveys are not exactly comparable among years because seasonal survey dates varied by $\sim 45 \mathrm{~d}$ among years.

The bioenergetics model successfully described the observed seasonal growth of YOY menhaden Brevoortia tyrannus and its interannual variability (Fig. 4). Within-season changes in growth rate were 

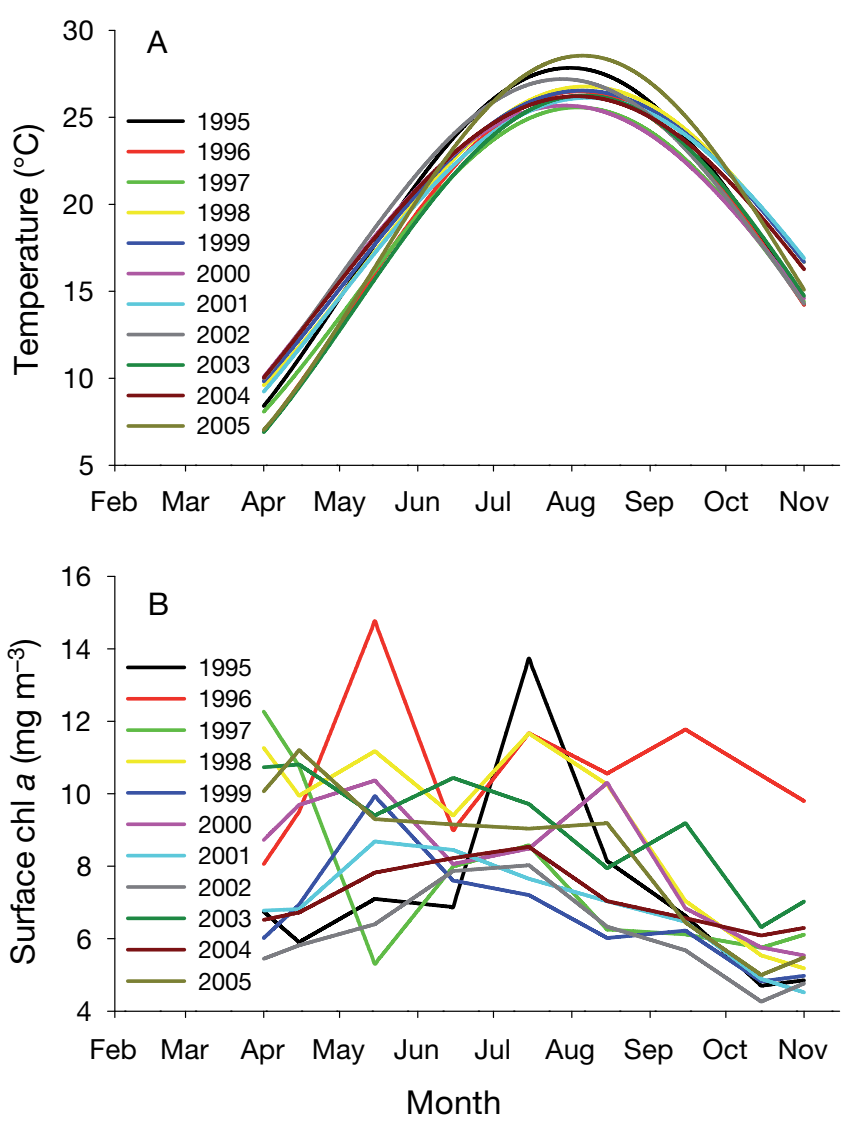

Fig. 3. Interpolated Chesapeake Bay (A) temperature and (B) chlorophyll a data for each year (1995 to 2005), used as inputs to the bioenergetics model

predominantly driven by the seasonality of temperature, while interannual differences were mostly responsive to varying chl a levels. Modeled growth rates were lowest in April and November. They were highest in July and August when maximum rates ranged from 0.035 to $0.060 \mathrm{~g} \mathrm{~g}^{-1} \mathrm{~d}^{-1}$, values equivalent to growth-in-length rates ranged from 0.75 to $1.63 \mathrm{~mm} \mathrm{~d}^{-1}$. Substantial differences in modeled length were attained by November of each year. Modeled lengths attained by 1 November ranged from $132.1 \mathrm{~mm}(22.7 \mathrm{~g})$ in 2002 to $208.2 \mathrm{~mm}$ (91.8 g) in 1996. The range of modeled lengths was similar, but slightly broader than observed lengths. The range of observed mean lengths in the fall surveys was from 131.4 to $183.9 \mathrm{~mm}$ (22.7 to $63.6 \mathrm{~g}$ ). The modeled length estimates for the corresponding dates ranged from 119.0 to $206.9 \mathrm{~mm}$ ( 16.5 to $90.1 \mathrm{~g})$. There were no significant trends in mean or maximum growth rates or sizes attained from 1995 to 2005.

Our preliminary model runs that assumed all chl a was available in the foraging model resulted in

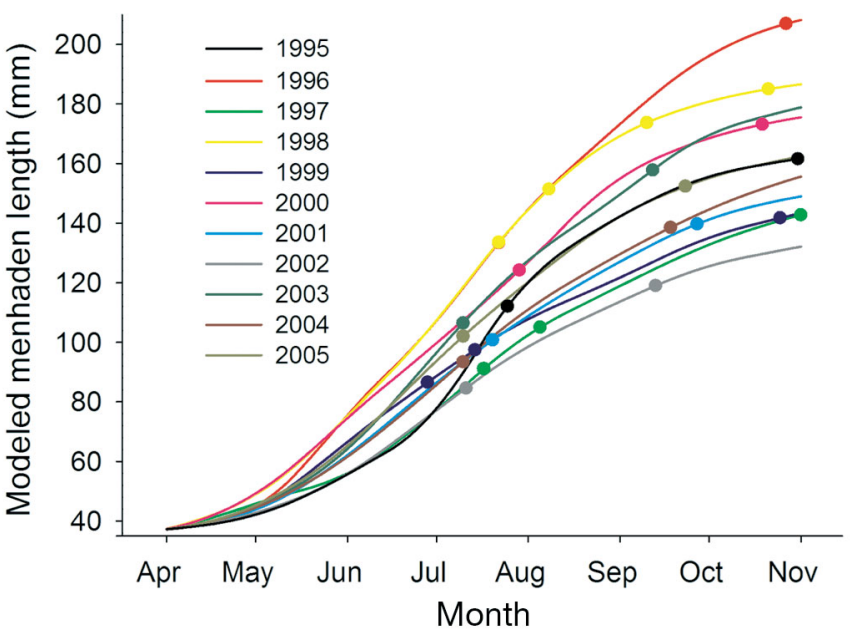

Fig. 4. Brevoortia tyrannus. Predicted growth of young-ofthe-year (YOY) Atlantic menhaden in each year (1995 to 2005) based on modeled growth rate potential. Filled circles denote lengths at dates in each year that correspond to TIES and CHESFIMS (see footnotes in 'Materials and methods') research survey collection dates. These points were used to calibrate the model to field measurements of YOY menhaden lengths. The model outputs from the years 1998, 2002, and 2004 were withheld from the initial calibration and subsequently used to evaluate model performance

unreasonably high growth rates, with peaks of 0.112 to $0.139 \mathrm{~g} \mathrm{~g}^{-1} \mathrm{~d}^{-1}$ and YOY menhaden length on 1 November of 350 to $400 \mathrm{~mm}$. We calibrated the model to provide a best fit to the research survey length measurements by reducing the pchl a term in the foraging model. The best fit was obtained with a pchl $a$ of $9.2 \%$ of chl a (Fig. 5A). The RMSE for the best model was $15.4 \mathrm{~mm}$, representing a relatively small error ( 7 to $12 \%$ of the modeled length), indicating a close fit of modeled lengths to lengths observed in the survey data. The slope of the relationship between modeled and observed lengths was near 1 (Fig. 5A).

The calibrated model was evaluated using the pchl a value 0.092, and chl a and temperature data for 3 reserved years: 1998, 2002, and 2004. The resulting comparison of modeled and observed lengths (Fig. 5B) indicated a reasonable match, with a RMSE of $16.5 \mathrm{~mm}$ and the slope of the comparison near 1. Except for the fall 2002 observed length, modeled lengths in these $3 \mathrm{yr}$ differed from observed menhaden lengths by only 5 to $10 \mathrm{~mm}$.

The mean estimates of YOY menhaden carrying capacity in biomass peaked early in the season at $50.4 \mathrm{~g} \mathrm{~m}^{-3}$, declined to a low of $10.5 \mathrm{~g} \mathrm{~m}^{-3}$ in early June, and increased gradually during the late sum- 


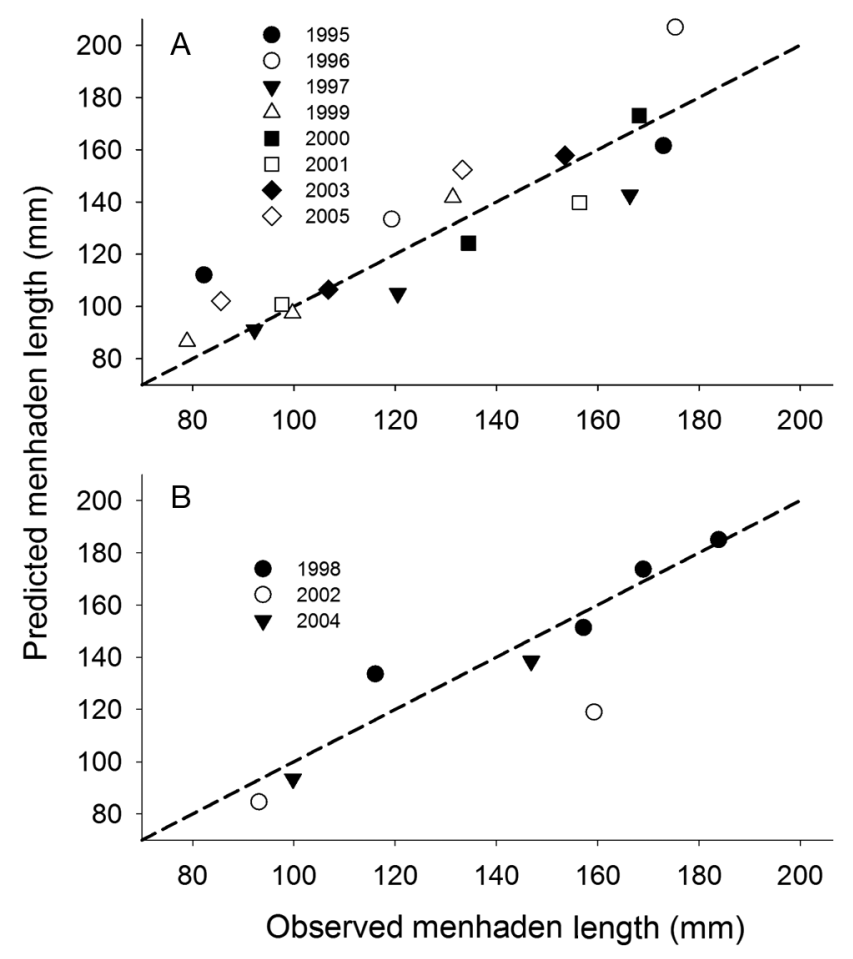

Fig. 5. Brevoortia tyrannus. (A) Calibration of modeled young-of-the-year Atlantic menhaden lengths relative to lengths observed during TIES and CHESFIMS (see footnotes in 'Materials and methods') surveys. (B) Evaluation of the model using 3 years of data that had been withheld from the calibration. Dashed lines depict 1:1 correspondence

mer and fall (Fig. 6). For individual years, the daily estimated carrying capacities (total number) for the mainstem bay ranged from $3.92 \times 10^{9}$ to $5.86 \times 10^{12}$ menhaden over the $11 \mathrm{yr}$ period (1995 to 2005), with maximum numbers in June and minimum numbers between late September and November. The mean carrying capacity for the mainstem of the bay on 1 November for the $11 \mathrm{yr}$ period was $21.1 \times 10^{9} \mathrm{YOY}$ menhaden (Fig. 6). The minimum carrying capacity for any day during a year, a potential bottleneck that might limit the number of menhaden produced, was $3.92 \times 10^{9}$ menhaden $\left(2.57 \times 10^{11} \mathrm{~g}\right)$ on 1 November 1998 , and the highest was $2.98 \times 10^{10}$ menhaden $\left(5.23 \times 10^{11} \mathrm{~g}\right)$ on 19 September 2002 .

Model runs using chl $a$ and temperature data averaged by regions of the bay indicated the highest growth potential for individual YOY menhaden in the oligohaline, up-estuary region, with substantially lower growth potential in the mesohaline and polyhaline regions (Fig. 7). Mean modeled menhaden length on 1 November was $203.9 \mathrm{~mm}(87.3 \mathrm{~g})$ in the oligohaline, $175.3 \mathrm{~mm}(54.9 \mathrm{~g})$ in the mesohaline, and $150.5 \mathrm{~mm}(34.4 \mathrm{~g})$ in the polyhaline region.

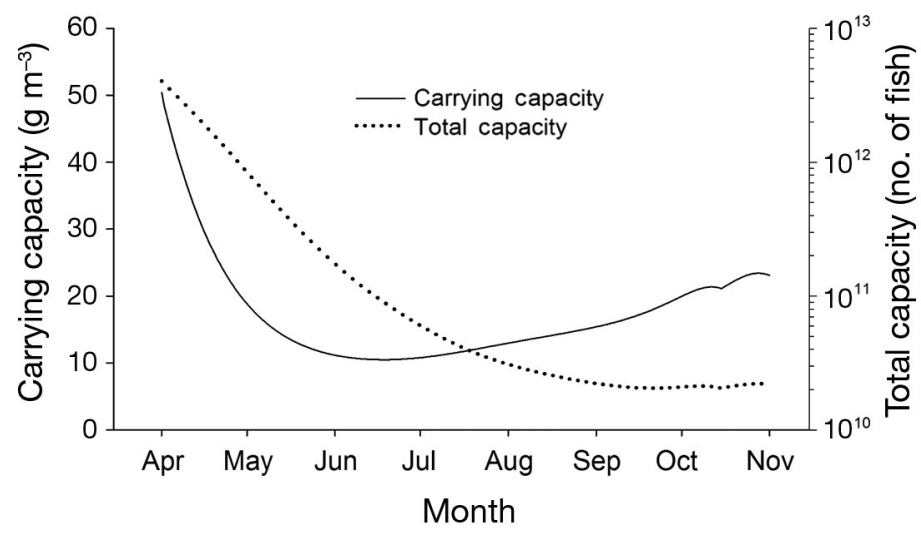

Fig. 6. Brevoortia tyrannus. Average (1995 to 2005) seasonal progression of carrying capacity $\left(\mathrm{g} \mathrm{m}^{-3}\right)$ and total capacity (numbers) for young-of-the-year Atlantic menhaden in the mainstem of Chesapeake Bay based on the output of the coupled foraging-bioenergetics model

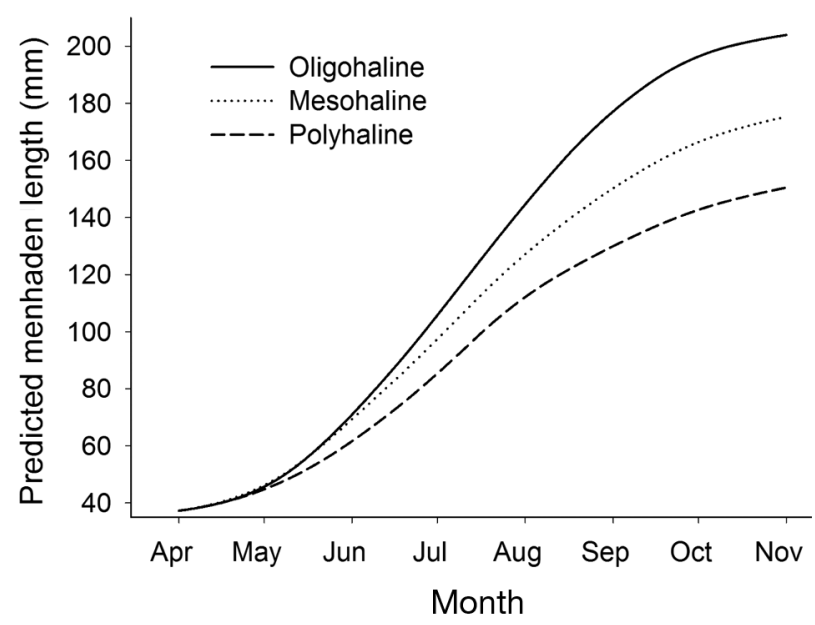

Fig. 7. Brevoortia tyrannus. Regional differences in growth potential for young-of-the-year Atlantic menhaden in the oligo-, meso- and polyhaline regions of Chesapeake Bay. Data represent the average growth potential for each region during the period from 1995 to 2005

\section{DISCUSSION}

Our coupled foraging-bioenergetics model successfully predicted YOY menhaden Brevoortia tyrannus lengths in Chesapeake Bay. The model captured variability in YOY menhaden growth based on field measurements of chl a and temperature and our improved functional responses for swimming speed and filtering efficiency. The model was calibrated and evaluated using bay survey data on YOY menhaden sizes. Calibration of the menhaden foraging- 
bioenergetics model to field data resulted in a close correspondence to menhaden size in Chesapeake Bay over a 2-fold range in fish lengths. The model was calibrated using lengths of trawl-sampled menhaden over an 11 yr period, with multiple data points available each year, broad ranges in temperature $\left(6.9\right.$ to $28.5^{\circ} \mathrm{C}$ ) and chl a levels (4.3 to $14.8 \mathrm{mg}$ $\mathrm{m}^{-3}$ ). Previous YOY menhaden bioenergetics models have relied on calibration based on field data from one location and season of data (Rippetoe 1993). Calibration of our model using bay-wide data over an $11 \mathrm{yr}$ period should improve the predictive ability of the model in the range of temperatures and chl $a$ levels typically encountered in Chesapeake Bay (Chipps \& Wahl 2008).

Modified functional responses improved the foraging component of the model, resulting in good fits to field data. We had observed that the Luo et al. (2001) foraging model underestimated YOY menhaden size in the early summer and greatly overestimated size in late summer and fall. Their functional responses for filtering efficiency and swimming speed did not allow positive growth potential in spring months when menhaden were small and water temperatures were cold. However, these conditions do in fact allow YOY menhaden to achieve substantial growth in Chesapeake Bay (E. D. Houde et al. unpubl. data). Our revised foraging models predicted higher growth rate potential early in the season compared to Luo et al.'s (2001) model, because of faster minimum swimming speed and higher filtering efficiency. Our modeled growth rates were lower in the latter half of the season because maximum swimming speed while filtering, and filtering efficiency were declining. Our adjustments resulted in a near 1:1 correspondence between predicted and observed lengths of YOY menhaden.

Developing a function that relates voluntary swimming speed to water temperature for menhaden was hindered by the paucity of information available. We developed our functional response using the sparse data available for YOY menhaden, and from characteristic responses of other species. The only published swimming speeds for filter-feeding YOY menhaden were from 1.43 to $1.99 \mathrm{BL} \mathrm{s}^{-1}$ at 24.4 to $27.2^{\circ} \mathrm{C}$ (Friedland et al. 1984). We used these values to define the maximum speed (1.99 $\left.\mathrm{BL} \mathrm{s}^{-1}\right)$ and optimum temperature $\left(26^{\circ} \mathrm{C}\right)$ in our functional response. An optimum temperature of $26^{\circ} \mathrm{C}$ is consistent with Lewis \& Hettler's (1968) description of active swimming of YOY menhaden at temperatures of 20 to $30^{\circ} \mathrm{C}$. Optimum swimming speed in fish often reflects the regional temperatures encountered in their dis- tribution (reviewed in Zeng et al. 2009), and we might expect optimum swimming speeds for YOY menhaden to occur in the range of the peak temperatures regularly encountered in the summer in Chesapeake Bay. Approximately $50 \%$ of our model run in each year was spent at temperatures $>22^{\circ} \mathrm{C}$. In our functional response model the temperature optimum resulted in peak swimming speed during the period of maximum summer water temperatures in Chesapeake Bay, which reached 25.6 to $28.5^{\circ} \mathrm{C}$ in our model runs.

Maximum swimming speed in previous models of menhaden foraging (Luo et al. 2001, Brandt \& Mason 2003, Dalyander \& Cerco 2010) was bounded by a maximum reported speed while filter-feeding of 2.5 BL s $^{-1}$ (Stage I feeding; Durbin \& Durbin 1975, Durbin et al. 1981, Friedland et al. 1984). However, our review of menhaden literature suggested that a maximum speed of $2.5 \mathrm{BL} \mathrm{s}^{-1}$ while filter-feeding was too high. Hydrodynamic drag is greatly increased during feeding activity in menhaden, and Durbin et al. (1981) concluded that the energetic cost of swimming at 2.0 to $2.5 \mathrm{BL} \mathrm{s}^{-1}$ could not be sustained, which was confirmed in experiments on metabolic rate as a function of swimming speed (Macy et al. 1999). Accordingly, we used Friedland et al.'s (1984) observed maximum sustained swimming speed for feeding YOY menhaden (Stage II feeding) as an upper bound for maximum speed.

We incorporated a strong positive relationship between swimming speed and temperature in our model because it fits descriptions and our understanding of this functional response in other fishes and in the early life stages of menhaden. Faster swimming speed at warmer temperatures is reported for a broad range of fish species and is attributed to faster biochemical reaction rates, improved muscle contraction and cardiac performance, and lower water viscosity (reviewed in MacNutt et al. 2004). When examined over a sufficiently broad range of temperatures, the functional response is often a bellshaped curve with swimming speed decreasing above an optimum temperature (Koumoundouros et al. 2002, Lee et al. 2003, MacNutt et al. 2004, Fangue et al. 2008, Zeng et al. 2009).

There is evidence for a positive relationship between temperature and swimming speed in the early life stages of menhaden. Hettler (1976) reported a strong positive relationship between temperature and swimming speed in late-stage menhaden larvae ( 24 to $28 \mathrm{~mm}$ ) for temperatures in the range of 14 to $24^{\circ} \mathrm{C}$. This range includes the steepest slope in the swimming speed-temperature func- 
tional response in our model. Hettler (1976) did not report swimming speeds for larger YOY menhaden, but did report increasing $\mathrm{O}_{2}$ consumption with increasing temperature for 5 to $80 \mathrm{~g}$ ( 80 to $200 \mathrm{~mm}$ ) menhaden, which are in the range of lengths in our model. He partially attributed increasing $\mathrm{O}_{2}$ consumption to increasing swimming speed with temperature. In contrast, voluntary swimming speeds reported for adult menhaden from 255 to $260 \mathrm{~mm}$ in length differed little in laboratory experiments at temperatures from 16 to $25^{\circ} \mathrm{C}$ (Durbin \& Durbin 1975, Durbin et al. 1981, Macy et al. 1999). These contrasting results from different life stages may indicate an ontogenetic shift in the functional response to temperature. A similar ontogenetic shift in temperature sensitivity was reported for alewife Alosa pseudoharengus, in which temperature significantly influenced juvenile swimming speed but not adult swimming speed (Klumb et al. 2003).

We conducted sensitivity analyses on the temperature-swimming speed functional response in our model to evaluate the parameters and shape of the function. Adjustments to the swimming speed parameters of $\pm 10 \%$ did not substantially alter our ability to fit the model output to field data. However, when we adjusted the parameters to a constant swimming speed across all temperatures or applied a linear increase in swimming speed with temperature, the resulting absence of a curvilinear response function made it difficult to simulate the inflection points of the seasonal growth curves observed in field data (Houde et al. 2009).

Luo et al. (2001) had adopted a functional form for swimming speed in perch Perca fluvatilis (Bergman 1987) as the basis for the sigmoid functional response in their YOY menhaden foraging model. We believe that we have improved the swimming speedtemperature functional response in our model by (1) adopting a bell-shaped functional form that is more commonly observed in response to temperature, (2) revising downward maximum swimming speeds to sustainable levels, and (3) increasing minimum swimming speeds to allow growth in cold waters early in the model-run season. The model output is sensitive to changes in swimming speed, and this is an area that warrants further research. Additional experiments on swimming speed of feeding YOY menhaden at low and high temperatures are needed to confirm and refine the precise shape of the curve and inflection points.

In the foraging model, we assumed that feeding continues throughout a $24 \mathrm{~h}$ day. Peck (1893) found full menhaden stomachs in individuals collected at night, and laboratory feeding experiments by Hettler (1976) confirmed that juvenile menhaden feed in darkness. In their foraging model, Durbin \& Durbin (1998) assumed a $12 \mathrm{~h} \mathrm{~d}^{-1}$ feeding period for menhaden, arguing that predator avoidance and migration activity might interfere with feeding in daylight hours, and feeding at night might be greatly reduced due to slower swimming speeds, as reported for Atlantic herring Clupea harengus (Batty et al. 1986). While numerous factors may reduce feeding time, we lacked data to develop a functional response for diel feeding and therefore assumed a $24 \mathrm{~h} \mathrm{~d}^{-1}$ feeding period. As such, the modeled feeding period probably exceeded the realized feeding period of menhaden. However, any error resulting from the feeding period assumption was compensated for by the pchl a term used to calibrate the model output to field data. If feeding duration is $<24 \mathrm{~h}$, then pchl $\mathrm{a}$ in our model is too low and would require adjustment upward to maintain model fit to menhaden length in the bay.

The new filtering efficiency functional response we used was based on recently reported ontogenetic changes in gillraker morphology (Friedland et al. 2006). As suggested by Friedland et al. (2006), filtration efficiency in small YOY menhaden may be higher than indicated by the gillraker spacing because of additional particle capture through clogging (Friedland et al. 1984), capture of particles on mucus, and crossflow filtration (Drenner et al. 1987, Sanderson et al. 2001, Smith \& Sanderson 2007). We calibrated our functional response to efficiencies estimated and reported in laboratory experiments (Durbin \& Durbin 1975, Friedland et al. 1984) that would include any factors contributing to additional particle capture.

The foraging model we employed does not account for size-selective filtration of particles in a natural phytoplankton community. Further refinement of the foraging model might be achieved through size fractionation of the chl a input data to include only chl a from the size fraction of phytoplankton likely to be retained on YOY menhaden gillrakers. Such an application could be useful, for example, to evaluate effects on menhaden filter-feeding of any long-term trends or shifts in dominance toward smaller primary producers in Chesapeake Bay (Marshall et al. 2005).

In laboratory experiments, Lynch et al. (2010) reported chl a ingestion rates of from 0.1 to $4.0 \mu \mathrm{g}$ fish $^{-1} \mathrm{~min}^{-1}$ for YOY menhaden $(73.6 \mathrm{~mm})$ that increased with chl a concentrations in a Type III sigmoid functional response curve. Our foraging model did not incorporate a functional response with re- 
spect to the available chl a concentrations. However, the chl a concentrations in our model were approaching the lower asymptote $\left(<15 \mu \mathrm{g} \mathrm{l}^{-1}\right)$ in Lynch et al.'s (2010) functional response curve, indicating there was little variation in ingestion as a function of concentration at these chl a levels. Ingestion of chl a by $\sim 73 \mathrm{~mm}$ menhaden in our model was equivalent to $0.17-0.26 \mu$ fish $^{-1} \mathrm{~min}^{-1}$ over a chl a range of 7.94 to $11.23 \mathrm{\mu g} \mathrm{l}^{-1}$, and is consistent with ingestion rates reported by Lynch et al. (2010) at low chl a levels.

The bioenergetics model might account for some of the unexplained variability in the length of menhaden field data if the diet were expanded to include foods other than phytoplankton. It is possible that our model slightly underestimates the sizes of older YOY menhaden because zooplankton prey is not included in the model. There is evidence that menhaden diet shifts from phytoplankton to zooplankton as menhaden increase in size (Durbin \& Durbin 1975, Friedland et al. 1984, Lynch et al. 2010). Detritus was also not included in our foraging model. It may comprise a significant portion of YOY menhaden diets, particularly when fish are in close proximity to salt marshes (Jeffries 1975, Peters \& Schaaf 1981, Lewis \& Peters 1994), but it is relatively low in energy content. Nevertheless, our model effectively estimates growth potential of YOY menhaden using only bulk chl $a$ as the food source.

In addition to diet considerations, variability of observed menhaden lengths may result from interannual differences in peaks of protracted offshore spawning and the timing of larval ingress to Chesapeake Bay that occurs over a several-month period (November to March). Another potential source of bias that we are unable to evaluate is gear selectivity by trawl sampling that might favor catches of smaller menhaden in our field samples. If that bias were significant it would result in a lower estimate of pchl $a_{\text {, }}$ and the upper range of modeled YOY menhaden length would underestimate the size of menhaden in the field.

A noteworthy outcome of our modeling was that the best fit between modeled and observed menhaden size was achieved by reducing the phytoplankton available for foraging to $9.2 \%$ of surface chl $a$ values. This suggests that only a small fraction of the standing stock of phytoplankton is required to support observed menhaden growth in the bay if menhaden are feeding $24 \mathrm{~h} \mathrm{~d}^{-1}$. Our $9.2 \%$ value is close to the estimate by Peters \& Shaaf (1981) that YOY menhaden might consume from 6 to $9 \%$ of primary production, and is similar to the $10 \%$ fraction of phytoplankton used to estimate the carrying capacity of YOY menhaden reported by Luo et al. (2001) and Brandt \& Mason (2003). Luo et al. (2001) selected $10 \%$ as a conservative assumption of the phytoplankton biomass available to menhaden after other consumers in the bay removed from 50 to $80 \%$ of phytoplankton production (Baird \& Ulanowicz 1989). Our $9.2 \%$ pchl a value should be interpreted cautiously because it compensates for any remaining errors in functional forms or assumptions in the model. For example, if the feeding period were actually only $12 \mathrm{~h} \mathrm{~d}^{-1}$, pchl a must double to maintain menhaden growth comparable to that observed in Chesapeake Bay. Filtering efficiency of YOY menhaden is size selective (Friedland et al. 1984) and, if chl $a$ in the model were limited to the size fractions retained (total chl a values were used in the model), would require an increase in pchl $a$ to achieve a close fit between model output and field data. If a substantial fraction of the food of YOY menhaden is zooplankton, then the pchl a value we report is too high.

Estimates of carrying capacity $\left(\mathrm{g} \mathrm{m}^{-3}\right)$ were similar to those reported for YOY menhaden in the Patuxent River between June and November (Brandt \& Mason 2003). Based on seasonal patterns in their estimated total carrying capacity (number of fish), Luo et al. (2001) suggested that low total carrying capacity in late fall might represent a bottleneck for Age 0 fish recruiting to the coast-wide population. However, they concluded that their total carrying capacity estimate of 10 billion fish on 1 November would be capable of supporting coast-wide recruitment. Our average (1995 to 2005) estimate of the number of YOY menhaden that can be sustained on 1 November was $\sim 2$ times higher than Luo et al.'s (2001) estimate (21 billion vs. 10 billion). We concur that estimates of total carrying capacity in late fall probably do not represent a bottleneck limiting recruitment of Age 0 menhaden to the coast-wide population.

The upper bay or oligohaline region had the highest modeled growth potential as a function of temperature and chlorophyll. Modeled menhaden size in the oligohaline was $37 \%$ greater in length and $266 \%$ greater in mass than in the polyhaline region. The result suggests that the upper bay is a particularly productive habitat for YOY menhaden. The growth potential for the 3 regions scaled with chl a levels that were consistently highest in the oligohaline region. Temperature was similar across the 3 regions. Observed abundances of YOY menhaden in the bay during summer are greatest near the head of the bay, corresponding to the region of high growth potential (Jung 2002). Preliminary analysis of regional variability in YOY menhaden size from the TIES and 
CHESFIMS surveys indicates that higher growth rates and larger size may be realized in the upestuary, oligohaline portions of the bay (Houde et al. 2009). Within tributaries of Chesapeake Bay and also in Pamlico Sound, North Carolina, juvenile menhaden abundance tends to be positively correlated with phytoplankton levels, suggesting that menhaden actively seek areas of high food availability (Friedland et al. 1989, 1996). Gulf menhaden Brevoortia patronus exhibits similar behavior, with latestage larvae moving to the heads of estuaries and into tributaries where feeding conditions for YOY menhaden are best (Deegan 1990).

Our evaluation of the coupled foraging and bioenergetics model using observed menhaden size data demonstrates the model's ability to realistically describe YOY menhaden growth. This development sets the stage for new, spatially explicit applications of the model and for extended analysis to include estimates of bay-wide menhaden production, phytoplankton consumption, and nutrient sequestration by filter-feeding menhaden. Several studies have made strong conceptual advances with respect to these applications (Luo et al. 2001, Brandt \& Mason 2003, Dalyander \& Cerco 2010) and warrant further examination using the recalibrated model presented here. In turn, such analyses will address issues related to managing the menhaden resource for sustainability and to insure conservation of its ecosystem services (MDSG 2009). The model could quantify ecosystem services provided by menhaden, thus helping to define the importance of bottom-up forcing in proposed ecosystem-based fisheries management.

Acknowledgements. This research was funded by National Oceanographic and Atmospheric Administration, Chesapeake Bay Office, Award Number NA04NMF4570359 to E.D.H. and L.W.H.Jr and for additional funding support from research contracts provided by Maryland Sea Grant Award NA05OAR4171042 and by the Maryland Department of Natural Resources Project K00P5201307. We thank T. Miller (Chesapeake Biological Laboratory) for access to and use of CHESFIMS data, and H. Austin and M. Fabrizio for menhaden data from the Virginia Institute of Marine Sciences trawl survey. We are grateful for stimulating discussions with W. Connelly, E. Martino, X. Zhang, and L. Bahner that helped to shape the project.

\section{LITERATURE CITED}

Adolf JE, Yeager CL, Miller WD, Mallonee ME, Harding LW (2006) Environmental forcing of phytoplankton floral composition, biomass, and primary productivity in Chesapeake Bay, USA. Estuar Coast Shelf Sci 67: 108-122
Ahrenholz DW (1991) Population biology and life history of the North American menhadens, Brevoortia spp. Mar Fish Rev 53:3-19

Ahrenholz DW, Guthrie JF, Krouse CW (1989) Results of abundance surveys of juvenile Atlantic and Gulf menhaden Brevoortia tyrannus and Brevoortia patronus. NOAA Tech Rep NMFS 84

ASMFC (Atlantic States Marine Fisheries Commission) (2010) Atlantic menhaden stock assessment and review panel reports. ASMFC, Washington, DC

Baird D, Ulanowicz RE (1989) The seasonal dynamics of the Chesapeake Bay ecosystem. Ecol Monogr 59:329-364

Batty RS, Blaxter JHS, Libby DA (1986) Herring (Clupea harengus) filter-feeding in the dark. Mar Biol 91: 371-375

Bergman E (1987) Temperature-dependent differences in foraging ability of two percids, Perca fluviatilis and Gymnocephalus cernuus. Environ Biol Fishes 19:45-53

Boicourt W, Kuzmie M, Hopkins TS (1999) The inland sea: circulation of Chesapeake Bay and the northern Adriatic. In: Malone TC, Alenka M, Harding LW Jr, Smodlaka N, Turner RE (eds) Ecosystems at the land-sea margin: drainage basin to coastal sea. American Geophysical Union, Washington, DC, p 81-130

Brandt SB, Mason DM (2003) Effect of nutrient loading on Atlantic menhaden (Brevoortia tyrannus) growth rate potential in the Patuxent River. Estuaries 26:298-309

CBFEAP (Chesapeake Bay Fisheries Ecosystem Advisory Panel) (2006) Trends in fisheries science and management. In: Fisheries ecosystem planning for Chesapeake Bay. American Fisheries Society, Bethesda, MD

Chipps SR, Wahl DH (2008) Bioenergetics modeling in the 21st century: reviewing new insights and revisiting old constraints. Trans Am Fish Soc 137:298-313

Cronin WB (1971) Volumetric, areal, and tidal statistics of the Chesapeake Bay estuary and its tributaries. Report No. 20, Chesapeake Bay Institute Special Report, Baltimore, MD

Cummins KW, Wuycheck JC (1971) Caloric equivalents for investigations in ecological energetics. Mitt Int Ver Theor Angew Limnol 18

> Dalyander P, Cerco CF (2010) Integration of a fish bioenergetics model into a spatially explicit water quality model: application to menhaden in Chesapeake Bay. Ecol Model 221:1922-1933

> Deegan LA (1990) Effects of estuarine environmental conditions on population dynamics of young-of-the-year gulf menhaden. Mar Ecol Prog Ser 68:195-205

Drenner RW, Vinyard GL, Hambright KD, Gophen M (1987) Particle ingestion by Tilapia galilaea is not affected by removal of gill rakers and microbranchiospines. Trans Am Fish Soc 116:272-276

> Durbin AG, Durbin EG (1975) Grazing rates of the Atlantic menhaden Brevoortia tyrannus as a function of particle size and concentration. Mar Biol 33:265-277

$>$ Durbin AG, Durbin EG (1998) Effects of menhaden predation on plankton populations in Narragansett Bay, Rhode Island. Estuaries 21:449-465

Durbin AG, Durbin EG, Verity PG, Smayda TJ (1981) Voluntary swimming speeds and respiration rates of a filterfeeding planktivore, the Atlantic menhaden, Brevoortia tyrannus (Pisces: Clupeidae). Fish Bull 78:877-886

$>$ Elliott JM, Davison W (1975) Energy equivalents of oxygen consumption in animal energetics. Oecologia 19: 195-201 
Fangue NA, Mandic M, Richards JG, Schulte PM (2008) Swimming performance and energetics as a function of temperature in killifish Fundulus heteroclitus. Physiol Biochem Zool 81:389-401

> Friedland KD, Haas LW, Merriner JV (1984) Filtering rates of the juvenile Atlantic menhaden Brevoortia tyrannus (Pisces: Clupeidae), with consideration of the effects of detritus and swimming speed. Mar Biol 84:109-117

Friedland KD, Ahrenholz DW, Guthrie JF (1989) Influence of plankton on distribution patterns of the filter-feeder Brevoortia tyrannus (Pisces: Clupeidae). Mar Ecol Prog Ser 54:1-11

$>$ Friedland KD, Ahrenholz DW, Guthrie JF (1996) Formation and seasonal evolution of Atlantic menhaden juvenile nurseries in coastal estuaries. Estuaries 19:105-114

Friedland KD, Ahrenholz DW, Smith JW, Manning M, Ryan J (2006) Sieving functional morphology of the gill raker feeding apparatus of Atlantic menhaden. J Exp Zool 305A:974-985

> Gottlieb SJ (1998) Nutrient removal by age-0 Atlantic menhaden (Brevoortia tyrranus) in Chesapeake Bay and implications for seasonal management of the fishery. Ecol Model 112:111-130

Hanson PC, Johnson TB, Schindler DE, Kitchell JF (1997) Fish bioenergetics 3.0. Report No. WISCU-T-97-001, University of Wisconsin Sea Grant Institute, Madison, WI

$>$ Harding LW Jr, Itsweire EC, Esaias WE (1994) Estimates of phytoplankton biomass in the Chesapeake Bay from aircraft remote sensing of chlorophyll concentrations, 1989-92. Remote Sens Environ 49:41-56

> Harding LW Jr, Mallonee ME, Perry ES (2002) Toward a predictive understanding of primary productivity in a temperate, partially stratified estuary. Estuar Coast Shelf Sci 55:437-463

> Harding LW Jr, Magnuson A, Mallonee ME (2005) SeaWiFS retrievals of chlorophyll in Chesapeake Bay and the MidAtlantic Bight. Estuar Coast Shelf Sci 62:75-94

$>$ Hartman KJ, Brandt SB (1995) Predatory demand and impact of striped bass, bluefish, and weakfish in the Chesapeake Bay-applications of bioenergetics models. Can J Fish Aquat Sci 52:1647-1666

- Hartman KJ, Kitchell JF (2008) Bioenergetics modeling: progress since the 1992 symposium. Trans Am Fish Soc 137:216-223

$>$ Hettler WF (1976) Influence of temperature and salinity on routine metabolic rate and growth of young Atlantic menhaden. J Fish Biol 8:55-65

Houde ED, Secor DH, Wilberg MJ (2009) Temporal and spatial variability in larval influx, production, and recruitment of young-of-the-year Atlantic menhaden and bay anchovy in Chesapeake Bay. Progress Report to NOAA Chesapeake Bay Office November 2009 Grant No NA07NMF4570340 [UMCES] CBL-09-129

Jeffries HP (1975) Diets of juvenile Atlantic menhaden (Brevoortia tyrannus) in three estuarine habitats as determined from fatty acid composition of gut contents. J Fish Res Board Can 32:587-592

June FC, Carlson FT (1971) Food of young Atlantic menhaden, Brevoortia tyrannus, in relation to metamorphosis. Fish Bull 68:493-512

Jung S (2002) Fish community structure and the spatial and temporal variability in recruitment and biomass production in Chesapeake Bay. PhD dissertation, University of Maryland, College Park, MD

Kitchell JF, Stewart DJ, Weininger D (1977) Applications of a bioenergetics model to yellow perch (Perca flavescens) and walleye (Stizostedion vitreum vitreum). J Fish Res Board Can 34:1922-1935

> Klumb RA, Rudstam LG, Mills EL (2003) Comparison of alewife young-of-the-year and adult respiration and swimming speed bioenergetics model parameters: implications of extrapolation. Trans Am Fish Soc 132: 1089-1103

> Koumoundouros G, Sfakianakis DG, Divanach P, Kentouri $M$ (2002) Effect of temperature on swimming performance of sea bass juveniles. J Fish Biol 60:923-932

> Lee CG, Farrell AP, Lotto A, MacNutt MJ, Hinch SG, Healey MC (2003) The effect of temperature on swimming performance and oxygen consumption in adult sockeye (Oncorhynchus nerka) and coho (O. kisutch) salmon stocks. J Exp Biol 206:3239-3251

> Lewis RM, Hettler WF (1968) Effect of temperature and salinity on the survival of young Atlantic menhaden, Brevoortia tyrannus. Trans Am Fish Soc 97:344-349

Lewis VP, Peters DS (1981) Vascular plant and detritus utilization by juvenile Atlantic menhaden. Estuaries 4:268

> Lewis VP, Peters DS (1984) Menhaden-a single step from vascular plant to fishery harvest. J Exp Mar Biol Ecol 84: 95-100

> Lewis VP, Peters DS (1994) Diet of juvenile and adult Atlantic menhaden in estuarine and coastal habitats. Trans Am Fish Soc 123:803-810

> Luo J, Hartman KJ, Brandt SB, Cerco CF, Rippetoe TH (2001) A spatially-explicit approach for estimating carrying capacity: an application for the Atlantic menhaden (Brevoortia tyrannus) in Chesapeake Bay. Estuaries 24: $545-556$

> Lynch PD, Brush MJ, Condon ED, Latour RJ (2010) Net removal of nitrogen through ingestion of phytoplankton by Atlantic menhaden Brevoortia tyrannus in Chesapeake Bay. Mar Ecol Prog Ser 401:195-209

> MacNutt MJ, Hinch SG, Farrell AP, Topp S (2004) The effect of temperature and acclimation period on repeat swimming performance in cutthroat trout. J Fish Biol 65: 342-353

Macy WI, Durbin AG, Durbin EG (1999) Metabolic rate in relation to temperature and swimming speed, and the cost of filter feeding in Atlantic menhaden, Brevoortia tyrannus. Fish Bull 97:282-293

Marshall HG, Burchardt L, Lacouture R (2005) A review of phytoplankton composition within Chesapeake Bay and its tidal estuaries. J Plankton Res 27:1083-1102

- Marshall HG, Lacouture RV, Buchanan C, Johnson JM (2006) Phytoplankton assemblages associated with water quality and salinity regions in Chesapeake Bay, USA. Estuar Coast Shelf Sci 69:10-18

MDSG (Maryland Sea Grant) (2009) Menhaden species team background and issues briefs. Maryland Sea Grant, College Park, MD. Available at: www.mdsg.umd.edu/ images/uploads/siteimages/Menhaden_Species_Team_ Briefs.pdf

Ney JJ (1990) Trophic economics in fisheries: assessment of demand-supply relationships between predators and prey. Rev Aquat Sci 2:55-81

> Paerl HW, Valdes LM, Peierls BL, Adolf JE, Harding LW (2006) Anthropogenic and climatic influences on the eutrophication of large estuarine ecosystems. Limnol Oceanogr 51:448-462

Peck JI (1893) On the food of the menhaden. Bull US Fish Comm 13:113-126 
Peters RH, Downing JA (1984) Empirical analysis of zooplankton filtering and feeding rates. Limnol Oceanogr 29:763-784

Peters DS, Schaaf WE (1981) Food requirements and sources for juvenile Atlantic menhaden. Trans Am Fish Soc 110: 317-324

Reintjes JW, Pacheco AL (1966) The relation of menhaden to estuaries. Spec Publ Am Fish Soc 3:50-58

Rippetoe TH (1993) Production and energetics of Atlantic menhaden in Chesapeake Bay. MSc thesis, University of Maryland, College Park, MD

Rogers SG, Van den Avyle MJ (1983) Species profiles: life histories and environmental requirements of coastal fishes and invertebrates (South Atlantic). Atlantic Menhaden. Report No. FWS/OBS-82/11.11, US Department of the Interior, Fish and Wildlife Service, Washington, DC

Sanderson SL, Angela YC, Jennifer SG, Jenny DG, Callan WT (2001) Crossflow filtration in suspension-feeding fishes. Nature 412:439-441

Smith JW (1999) Distribution of Atlantic menhaden,

Editorial responsibility: Edward Durbin,

Narragansett, Rhode Island, USA
Brevoortia tyrannus purse-seine sets and catches from southern New England to North Carolina, 1985-96. NOAA Tech Rep NMFS 144

Smith JC, Sanderson S (2007) Mucus function and crossflow filtration in a fish with gill rakers removed versus intact. J Exp Biol 210:2706-2713

Thornton KW, Lessem AS (1978) A temperature algorithm for modifying biological rates. Trans Am Fish Soc 107: $284-287$

Viverette CB, Garman GC, McIninch SP, Markham AC, Watts BD, Macko SA (2007) Finfish-waterbird trophic interactions in tidal freshwater tributaries of the Chesapeake Bay. Waterbirds 30:50-62

Walter JF, Overton AS, Ferry KH, Mather ME (2003) Atlantic coast feeding habits of striped bass: a synthesis supporting a coast-wide understanding of trophic biology. Fish Manag Ecol 10:349-360

Zeng LQ, Cao ZD, Fu SJ, Peng JL, Wang YX (2009) Effect of temperature on swimming performance in juvenile southern catfish (Silurus meridionalis). Comp Biochem Physiol A Mol Integr Physiol 153:125-130

Submitted: May 26, 2010; Accepted: June 3, 2011

Proofs received from author(s): August 29, 2011 